Egyptian Journal of Aquatic Biology \& Fisheries

Zoology Department, Faculty of Science,

Ain Shams University, Cairo, Egypt.

ISSN $1110-6131$

Vol. 23(1): 135 - 150 (2019)

www.ejabf.journals.ekb.eg

\title{
Community Composition of Zooplankton in El-Rayah El-Behery, Egypt.
}

\author{
Mohamed R. Fishar ${ }^{1}$;Neveen H. Mahmoud ${ }^{2}$; Faten A. El- Feqy ${ }^{2}$ and \\ Khadiga M. G. Gaber ${ }^{1 *}$ \\ 1- National Institute of Oceanography and Fisheries, Cairo, Egypt. \\ 2- Faculty of Science, Al-Azhar University, Caito, Egypt. \\ *Corresponding author: khadiga.mgg2008@yahoo.com
}

\section{ARTICLE INFO \\ Article History: \\ Received: Dec. 31, 2018 \\ Accepted: Jan. 30, 2019 \\ Online: Feb. 2019}

Keywords:

Zooplankton

El-Rayah El-Behery

Water quality

Environmental variables
ABSTRACT

The abundance and diversity of zooplankton has been studied in relation to some environmental variables in El-Rayah El-Behery (one of the main irrigating canals of Nile Delta). Eight physical and chemical parameters were investigated for water quality assessment during the period from autumn to winter 2014.The results indicate that, there was negative correlation between temperature, $\mathrm{pH}$ and zooplankton. Rotifers have high positive correlation with nutrient and EC, while Protozoa was positively affected by DO. Sixty one species of zooplankton had been identified during the present survey (42 Rotifera, 9 Protozoa, 7 Cladocera and 3 Copepoda). The highest number of species and diversity index $(S=56$ and 2.8) were recorded at B1 and B5, while the lowest value was recorded at B6 $(\mathrm{S}=40)$. Rotifers formed a main component of zooplankton, which indicates eutrophic state of El-Rayah El-Behery. Prolides sp. was the main rotifer species during the present study. It was recorded at all sampling stations and was found in all seasons. Vorticella campanula was the most abundant protozoan; it contributed about $42.1 \%$ of the total Protozoa populations and flourished in summer. Bosmina longirostris was the most dominant species of cladocera and was represented by about $58.9 \%$ of total Cladocera. The highest bulk of total copepods was represented by Nauplius larvae, which recorded about $74.8 \%$ of total copepods. There was a sharp increasing in total zooplankton during spring with an average of $1348750 \mathrm{Ind} / \mathrm{m}^{3}$ and a marked decrease during summer with an average number of $635750 \mathrm{Ind} / \mathrm{m}^{3}$.

\section{INTRODUCTION}

El-Rayah El-Behery is one of four rayahs are branched from the Nile at the Delta Barrages. The main use of rayahs is drinking, irrigation, navigation and fishing purposes likewise the River Nile. El-Rayah El-Behery is receiving wastewater and agricultural drainage water which has a lot of negative effects on aquatic fauna and flora. Furthermore, effluents transport large volumes of polluting chemical compounds such as heavy metals, hydrocarbons, pesticides and other toxic organic compounds, Fleeger et al. (2003) and Caulleaud et al. (2009).

Zooplankton is major components in the trophic dynamics of freshwater ecosystems. They occupying intermediate position in the food chain and indicate the environmental status. 
This significant role due to their significant capacity to accumulate heavy metals, and their essential role in the enrichment of anthropogenic compounds in food chains (Stemberger and Chen, 1998). Also their respond to a wide variety of disturbances including nutrient loading, Dodson (1992), acidification (Armorek and Kormann, 1993), fish densities (Carpenter and Kitchell, 1993), contamination, Yan et al.(1996), and sediment inputs, Cuker (1997).

Many studies had been carried out on the River Nile, and its branches. Most of these studies concerned with the state of the water quality such as: Abdel-Hameid et al. (1992) \& Abdel-Aziz (2005) and El Bouraie et al. (2011). Other studies concerned with the effect of pollution on the zooplankton densities and distribution Aboul-Ezz et al. (1996) \& El-Bassat, (2002) \& El-Shabrawy et al (2005) \& Hegab (2010) \& Gaber (2013) \& (Khalifa and Bendary, 2016)

The objective of this study is to determine some physico-chemical variables of the water of El-Rayah El-Behery as well as, its effect on distribution and seasonal changes of zooplankton.

\section{MATERIALS AND METHODS}

\section{Sites study:}

El-Rayah El-Behery is one of three rayahs are branched from the Rosetta branch at the Delta Barrages, it starts from Rosetta branch at El-Kanater El-Khayria city and extends into the West of Delta, parallel to Rosetta branch and west of Giza governorate then breaking Behera governorate and Alexandria. El-Rayah El-Behery meets with El Mahmudiyah canal after Damanhur city.

This rayah extends with average length of $220 \mathrm{Km}$ from El-Kanater and with average width $40-50 \mathrm{~m}$ and its average depth $2-3 \mathrm{~m}$. This rayah characterized by existence of many water plants and electricity stations on its beaches especially on El Mahmudiyah canal that supply water to Behera and Alexandria governorates. The stations that have been collected from this Rayah were eight stations (B1-B8) as in Table (4) and Figure (1).

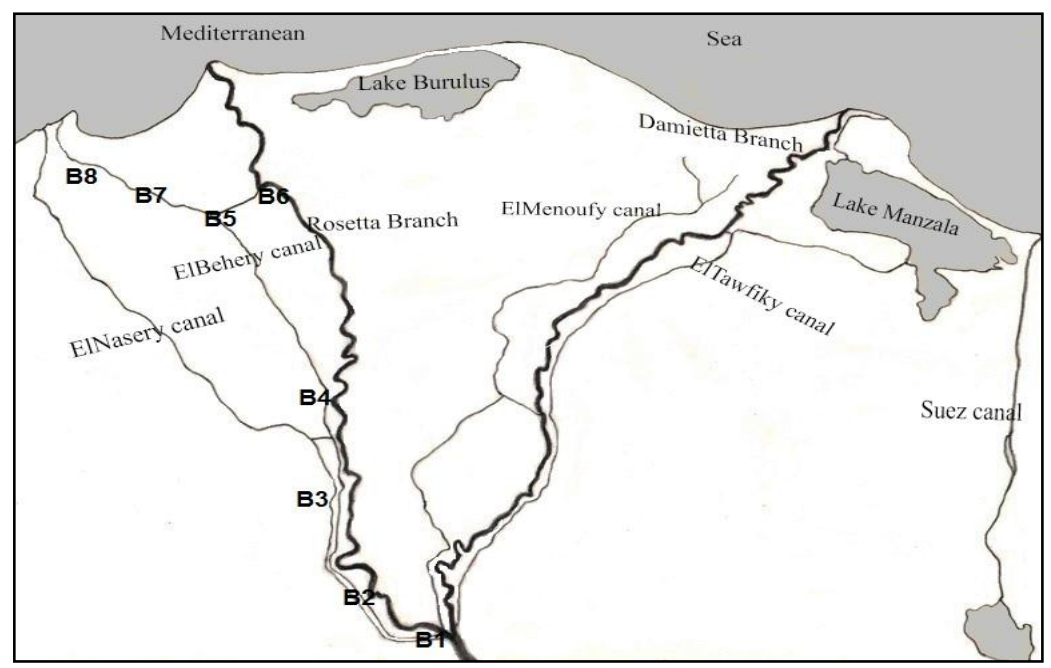

Fig. 1: Map of El-Rayah El-Behery demonstrating the collected Stations. 
Table 1: The collecting stations of El-Rayah El- Behery and its corresponding Longitude and Latitude.

\begin{tabular}{|c|c|c|c|c|c|}
\hline $\begin{array}{c}\text { St } \\
\text { Code }\end{array}$ & Name & Latitude & Longitude & $\begin{array}{l}\text { Distance } \\
\text { from El- } \\
\text { Kanater) }\end{array}$ & Description \\
\hline B1 & $\begin{array}{l}\text { starting of rayah } \\
\text { at El kanater }\end{array}$ & $30^{\circ} 10^{\prime} 47.36^{\prime \prime}$ & $31^{\circ} 6^{\prime} 18.69^{\prime \prime}$ & $3-4 \mathrm{Km}$ & $\begin{array}{l}\text { Middle of industrial and } \\
\text { agricultural regions / receives } \\
\text { few wastewater }\end{array}$ \\
\hline B2 & Abo Ghaleb & $30^{\circ} 14^{\prime} 46.90^{\prime \prime}$ & $30^{\circ} 56^{\prime} 33.68^{\prime \prime}$ & $30 \mathrm{Km}$ & $\begin{array}{l}\text { Located immediately after } \\
\text { electricity station (Abu } \\
\text { ghaleb)/agricultural region in } \\
\text { east side }\end{array}$ \\
\hline B3 & Kaffr Dawood & $30^{\circ} 27^{\prime} 3.75^{\prime \prime}$ & $30^{\circ} 49^{\prime} 41.35^{\prime \prime}$ & $65 \mathrm{Km}$ & $\begin{array}{l}\text { In the way of khatatba city/ } \\
\text { Middle of agricultural and } \\
\text { residential regions }\end{array}$ \\
\hline B4 & El-Tawfikia & $30^{\circ} 48^{\prime} 36.91^{\prime \prime}$ & $30^{\circ} 45^{\prime} 21.65^{\prime \prime}$ & $90-100 \mathrm{Km}$ & $\begin{array}{lrr}\text { Under El-Tawfikia } & \text { bridge/ } \\
\text { beside } & \text { agricultural } & \text { way } \\
\text { (Cairo-Alexandria) } & \\
\end{array}$ \\
\hline B5 & Damanhour & $31^{\circ} 00^{\prime} 46.5^{\prime \prime}$ & $30^{\circ} 28^{\prime} 52.8^{\prime \prime}$ & $135 \mathrm{Km}$ & $\begin{array}{l}\text { Damanhour city entrance/ The } \\
\text { Distance between it and } \\
\text { agricultural way }(2 \mathrm{Km})\end{array}$ \\
\hline B6 & El-Mahamoudiah & $31^{\circ} 10^{\prime} 25.9^{\prime \prime}$ & $30^{\circ} 31^{\prime} 42.1^{\prime \prime}$ & $140 \mathrm{Km}$ & $\begin{array}{l}\text { The beginning of } \text { El- } \\
\text { Mahmudiyah conduit /The } \\
\text { Distance between it and } \\
\text { Rosetta branch }(1 \mathrm{Km})\end{array}$ \\
\hline B7 & $\begin{array}{l}\text { Meeting ElRayah } \\
\text { with El- } \\
\text { Mahamoudiah } \\
\text { Canal }\end{array}$ & $31^{\circ} 5^{\prime} 16.85^{\prime \prime}$ & $30^{\circ} 25^{\prime} 16.79^{\prime \prime}$ & $145 \mathrm{Km}$ & $\begin{array}{l}\text { Located after the confluence } \\
\text { El-Rayah with El-Maham- } \\
\text { oudiah/Middle of huge } \\
\text { residential region }\end{array}$ \\
\hline B8 & Kaffr El-Dawar & $31^{\circ} 7^{\prime} 31.58^{\prime \prime}$ & $30^{\circ} 13^{\prime} 31.82^{\prime \prime}$ & $180 \mathrm{Km}$ & $\begin{array}{l}\text { Middle of agricultural and } \\
\text { residential regions in the right } \\
\text { and left sides/Low water level }\end{array}$ \\
\hline
\end{tabular}

\section{Sampling:}

Samples were conducted seasonally throughout 2014. All samples were collected from surface water from each station. Prior to sampling, the $\mathrm{pH}$, dissolved oxygen, water temperatures and electrical conductivity were measured in situ using portable meters. Also, the nutrient salts which included Ammonia, Nitrite, Nitrate and Orthophosphate were measured by using spectrophotometer, model Kontron instrument, Uvikon 930.

Thirty liters of each water sample were filtered through a zooplankton net of $55 \mu \mathrm{m}$ mesh diameter. Samples were subsequently taken back to the laboratory and preserved in $4 \%$ formaldehyde. Rose Bengal was added to facilitate separation of organisms from the suspended matter. Sub samples of $1 \mathrm{ml}$ were drawn from each sample (after careful mixing) using a wide-pipette, McCallum (1979). The contents of such pipette were let to flow freely into $1 \mathrm{ml}$ Sedgwick-Rafter cell. Three successive sub samples were examined under a binocular compound microscope at 10x magnification. Identification of various taxes was based on the works of Edmondson (1959) and (Foissner and Berger, 1996).

\section{Data analysis:}

1. The diversity indices of zooplankton species were seasonally calculated as Species Richness, Shannon-Weaver Diversity Index and Index of Evenness by using Primer 5 (2001).

2. The similarity between the different stations for hydrographic conditions and species composition were done by using primer 5 . 
3. The relationship between the zooplankton and water quality variables were analyzed by canonical correspondence analysis (CCA) using Brodgar Program, version 2.4.8 (Highland Statistics, 2005).

\section{RESULTS AND DISCUSSION}

\section{Physico- chemical analysis:}

The physico-chemicals parameters of El-Rayah El- Behery were determined seasonally and nearly similar in variation as shown in Table (2). Temperature considered important factor which affecting directly or indirectly not only on population density, species composition and richness of rotifers in freshwaters, but also on their growth activity, activation of reproduction processes and susceptibility to diseases, Moustafa et al. (2010). Water temperature recorded the maximum value in summer with average of $31.1 \mathrm{C}^{\circ}$ and decreased to minimum reading $17.8 \mathrm{C}^{\mathrm{o}}$ in winter. The high temperature in summer was due to clear atmosphere and great solar radiation and it low values during winter were due to frequent clouds, high humidity and velocity, Shama et al. (2011).

During the present study, $\mathrm{pH}$ values were on the alkaline side along the year and recorded the maximum value during summer with average of 8.6 and the minimum reading during winter with average of 8.0. According to CCA analysis, $\mathrm{pH}$ was showed positive correlation with temperature. The highest values during summer was related to photosynthesis and growth of plants and the lowest values during winter was related to the high concentration of bicarbonate $\left(\mathrm{HCO}_{3}\right)$ in water due to the decreased uptake of $\mathrm{CO}_{2}$ by phytoplankton, Sabae (2004) and Abdel-Satar (2005).

Electrical conductivity (EC) was recorded the highest values during winter with average of $576.1 \mu \mathrm{gS} / \mathrm{cm}$ and the minimum values during spring $(392.4 \mu \mathrm{gS} / \mathrm{cm})$. The highest value of electrical conductivity could be due to the high pollution levels in water, resulted from the high nutrient loads of wastewater, Kobbia et al. (1995) \& (Fathi and Al-Kahtani, 2009). The lowest reading of EC during hot seasons in River Nile may be attributed to the increase of water level during flood period and uptake of dissolved salts by phytoplankton, Saad et al. (2011)

The presence of oxygen in water is an important factor for most aquatic plants and animals to survive and plays an important role in the occurrence and abundance of plankton (Stahl and Ramadan, 2008). The dissolved oxygen was recorded the highest average $(7.9 \mathrm{mg} / \mathrm{l})$ during spring and the minimum value $(5.8 \mathrm{mg} / \mathrm{I})$ during autumn. The highest values of DO during spring were due to the flourishing of phytoplankton and high movement of water which increase the mixing of water, Abdel-Satar (2008). The lowering of DO during autumn was may be related to the high transport of organic pollution and nutrients combined with low effluent rate and microbial decomposition of the organic matter, Goher (1998).

The high concentrations of ammonia were observed during cold seasons and the low concentrations were recorded during hot seasons. The highest concentration of ammonia may be related to the effect of industrial and agriculture wastes into the aquatic environment, Abdo (2013) and the decreasing in ammonia may be due to the oxidation by phytoplankton, Elewa (1993).

Results of nutrients indicated that, nitrite was showed the highest values during autumn and the lowest values were recorded during spring. The increase in $\mathrm{NO}_{2}$ during autumn might be attributed to low consumption by phytoplankton as well as the oxidation of ammonia by nitrifying bacteria and biological nitrification, Sayed (2003) and Abdo et al . (2010). The nitrate was recorded the highest concentrations 
during autumn and decreased to the lowest concentrations during summer. Tayel (2003) believed that, the high concentrations of nitrate may be due to the high quantity of organic materials and dissolved nitrate fertilizers washed down to the stream. The orthophosphate levels were increased during winter and decreased to the minimum levels during summer. The highest concentrations of orthophosphate may be attributed to the large amount of organic materials resulting from sewage, domestic, agricultural and industrial effluents.

Table 2: Seasonal variation of physico-chemical parameters of El-Rayah El-Behery

\begin{tabular}{|l|c|c|c|c|}
\hline & Autumn & Spring & Summer & Winter \\
\hline Temp ${ }^{0} \mathrm{C}$ & 23.0 & 27.0 & 31.1 & 17.8 \\
\hline $\mathrm{EC} \mu \mathrm{gS} / \mathrm{cm}$ & 494.5 & 392.4 & 402.8 & 576.1 \\
\hline $\mathrm{pH}$ & 8.3 & 8.3 & 8.6 & 8.0 \\
\hline $\mathrm{DO} \mathrm{mg} / \mathrm{l}$ & 5.8 & 7.9 & 6.4 & 7.2 \\
\hline $\mathrm{NH} 3 \mathrm{mg} / \mathrm{l}$ & 1137.5 & 301.5 & 477.3 & 2604.1 \\
\hline $\mathrm{NO} 2 \mathrm{mg} / \mathrm{l}$ & 162.0 & 8.4 & 55.0 & 46.6 \\
\hline $\mathrm{NO} 3 \mathrm{mg} / \mathrm{l}$ & 665.8 & 206.9 & 114.2 & 179.9 \\
\hline $\mathrm{PO} 4 \mathrm{mg} / \mathrm{l}$ & 64.3 & 16.2 & 70.7 & 143.6 \\
\hline
\end{tabular}

\section{Zooplankton Composition and Distribution}

In the investigated area, the zooplankton was represented by four main groups Rotifer, protozoa, cladocera and copepod, in addition to several other rare forms belonging to other taxonomical categories namely (Meroplankton), Figure (2). Rotifers were the dominant group of zooplankton representing $88.2 \%$. This result was recorded in the Nile water by many authors, khalifa (2000) \& Abd El-Mageed (2001) \& Abo Taleb (2009) \& Hegab (2010) and Gaber (2013). The dominance of rotifers in rivers may be related to their ability to reproduce over a wide temperature range, Galkovskaja (1987), their short generation time compared to the larger crustacean zooplankton (Van Dijk and Van Zanten, 1995), their simple parthenogentic reproduction which in favorable conditions results in high production rates (Andrew and Fizsimons, 1992) and the eutrophication condition of water affect the composition of zooplankton, shifting the dominance from large species (Copepoda) to smaller species (Rotifer), El-Shabrawy (2000) \& Emam (2006) and Mola (2011).

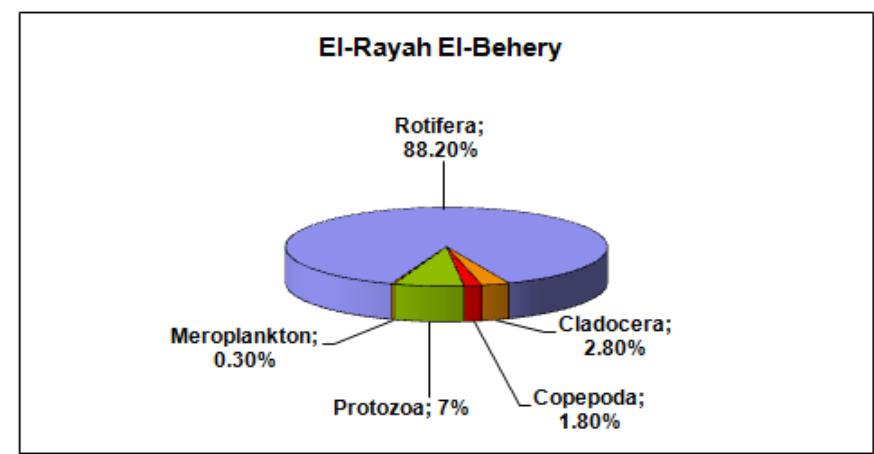

Fig. 2: faunal composition of zooplankton in El-Rayah El-Behery.

\section{Rotifers}

The maximum density of Rotifer was recorded at B6 with average of $1305000 \mathrm{Ind} / \mathrm{m}^{3}$ and decreased toward the downstream to the minimum value of density $583500 \mathrm{Ind} / \mathrm{m}^{3}$ at B8. There was a remarkable increasing in the average density of rotifers from $477250 \mathrm{Ind} / \mathrm{m}^{3}$ in summer to $1195500 \mathrm{Ind} / \mathrm{m}^{3}$ in spring, Figure (3). This result agrees with Amer (2007) \& Khalifa (2014) and (Khalifa and Bendary, 2016). 


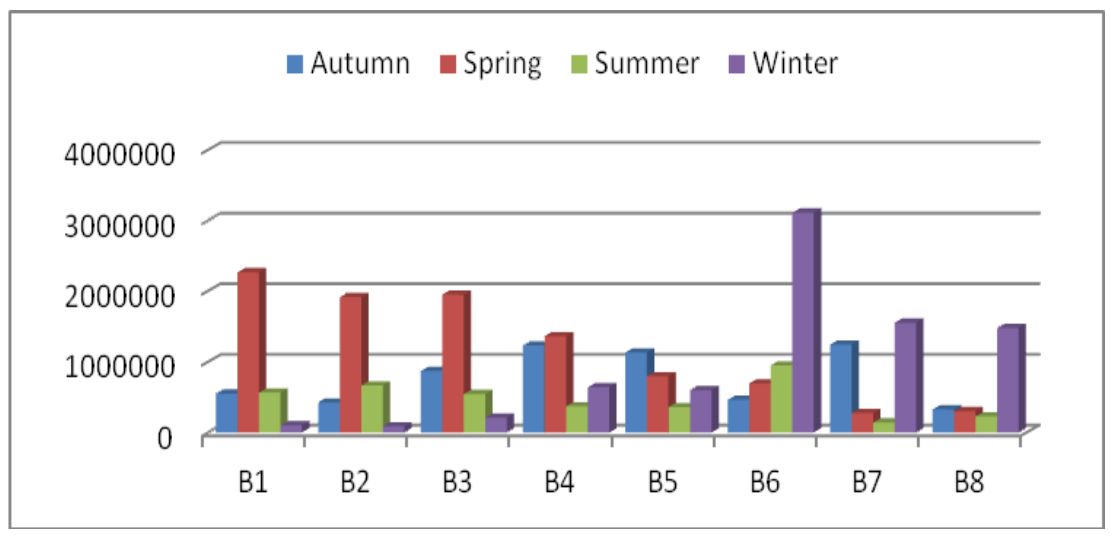

Fig. 3: Distribution and seasonal variation of Rotifers in El-Rayah El-Behery.

The diversity analysis of rotifers showed that, B2 \& B3 and B5 have the maximum number of species and richness $(\mathrm{S}=34$ and $\mathrm{d}=2.4)$ and $\mathrm{B} 6$ has the lowest number of species $(\mathrm{S}=25)$ \& richness $(\mathrm{d}=1.7)$ and diversity index $(1.5)$ while it has the maximum number of individuals $(\mathrm{N}=1305000)$. The sampling sites within cluster analysis divided into two clusters with similarity of $60 \%$. The first cluster included stations from B1 to B5, within this cluster the highest similarity was detected between B1 and B2 (more than 90\%). The second cluster included stations B6 \&B7 and B8 with similarity more than 75\%, Figure (4).

Table 3: Species diversity of total rotifers in El-Rayah El-Behery during 2014.

\begin{tabular}{|c|c|c|c|c|c|}
\hline Sample & $\begin{array}{c}\text { No. of } \\
\text { species }\end{array}$ & $\begin{array}{c}\text { No .of } \\
\text { Individuals }\end{array}$ & Richness (d) & Evenness $\left(\mathbf{J}^{\prime}\right)$ & $\begin{array}{c}\text { Shannon } \\
\text { Index }\left(H^{\prime}\right)\end{array}$ \\
\hline B1 & 33 & 871500 & 2.3 & 0.65 & 2.29 \\
\hline B2 & 34 & 774000 & 2.4 & 0.65 & 2.30 \\
\hline B3 & 34 & 894000 & 2.4 & 0.62 & 2.19 \\
\hline B4 & 31 & 900000 & 2.2 & 0.66 & 2.25 \\
\hline B5 & 34 & 721000 & 2.4 & 0.69 & 2.44 \\
\hline B6 & 25 & 1305000 & 1.7 & 0.48 & 1.55 \\
\hline B7 & 29 & 803000 & 2.1 & 0.56 & 1.88 \\
\hline B8 & 32 & 583500 & 2.3 & 0.46 & 1.60 \\
\hline
\end{tabular}

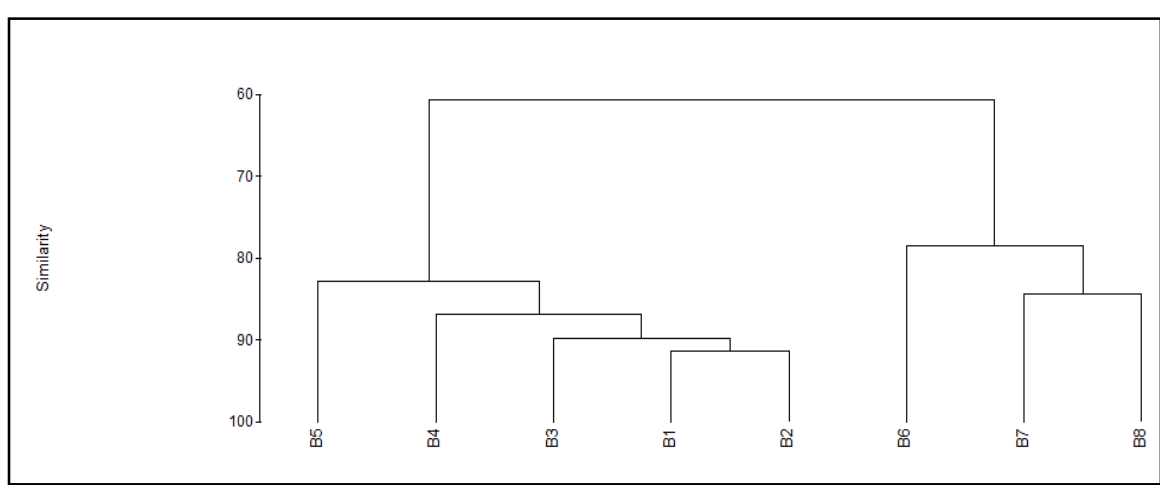

Fig. 4: Cluster analysis similarity between sampling sites of total rotifer at El-Rayah El-Behery

A total of 41 species of rotifers belonged to 23 genera were recorded during the present study. Proalides, Keratella, Brachionus, Trichocerca, Polyarthra and Philodina were the most dominant genera of Rotifer. Genus Proalides was represented at all sampling stations and found in all seasons. It contributed about $18 \%$ of total rotifer with an average number $154250 \mathrm{Ind} / \mathrm{m}^{3}$. (El-Shabrawy and Dumont, 2003) \& Saad et al. (2013) and (El-Shabrawy and Germoush, 2014) found that, 
Prolides sp. was one of the dominant rotifer species in many freshwater bodies in Egypt. It attained its highest population density in spring and the minimum value in winter. Genus keratella was the second dominant Rotifer's genus which represented by $K$. cochlearis and $k$. tropica. K.cochlearis contributed about $13.2 \%$ with average number $112875 \mathrm{Ind} / \mathrm{m}^{3}$ and recorded the highest density in spring where the lowest density was observed in autumn season. This species is one of the most common representatives of the family Brachionidae and is known to inhabit a diverse range of waters (Pejler and Bērziņš, 1989) and Koste (1978). Keratella tropica formed 7.48\% of total rotifer with average of $64063 \mathrm{Ind} . / \mathrm{m}^{3}$. it was flourished during autumn and sharply decreased to the minimum density value during winter.

Genus Brachionus was represented by eight species; however their densities were very low throughout the study period. According to Abd El-Mageed (2008) and Perbiche-Neves (2013), high richness of Brachionidae indicates eutrophic conditions Kumari et al. (2008) described Keratella sp. and Brachionus sp. as pollution indicator species. El-Bassat (1995) referred that high existence of these genus at Delta Barrage was attributed to their ability to tolerate pollution. The high peaks of these species were observed at stations B6 \& B7 and B8. This result may be to the highest values of EC and nutrients at these stations. (Abdel Aziz and Aboul-Ezz, 2004) reported that $B$. calyciflorus prefers mixotrophic environments rich in nutrients.

Trichocerca represented by four species T.Pusilla, T.olngata, T.cylindrica and T.porcellus. Among which T. pusilla dominated and detected about represent $3.7 \%$ of rotifer with an average of $31938 \mathrm{Ind} . / \mathrm{m}^{3}$. It flourished in autumn and decreased to the lowest density in winter season. This result agrees with Bedair (2006), He believed that, this species preferred low temperature.

The population density of Polyarthra vulgaris constituted $8.8 \%$ of total rotifers and flourished during in autumn but its density crop decreased in winter. This result agreed with Khalifa (2000, 2014) \& El-Bassat (2002) and George (2012) whereas they recorded the dominance of this species in late spring and autumn.

\section{Protozoa}

Protozoa was the second group of zooplankton during the present study, similar results were obtained by Hegab (2010) \& George (2012) and (Khalifa and Bendary, 2016). It recording the maximum value (143000 Ind. $/ \mathrm{m}^{3}$ ) at $\mathrm{B} 1$ and there was remarkably decreasing at the three last stations recording the minimum density (14500 Ind. $/ \mathrm{m}^{3}$ ) at B8. This may be attributed to the highest value of nutrient components at these stations. Emam (2006) concluded that, protozoa are pollution tolerant group of zooplankton and attained its highest density at the polluted area. It flourished during summer and sharply decreased during winter season. It was recorded negative correlation with temperature, Figure (5).

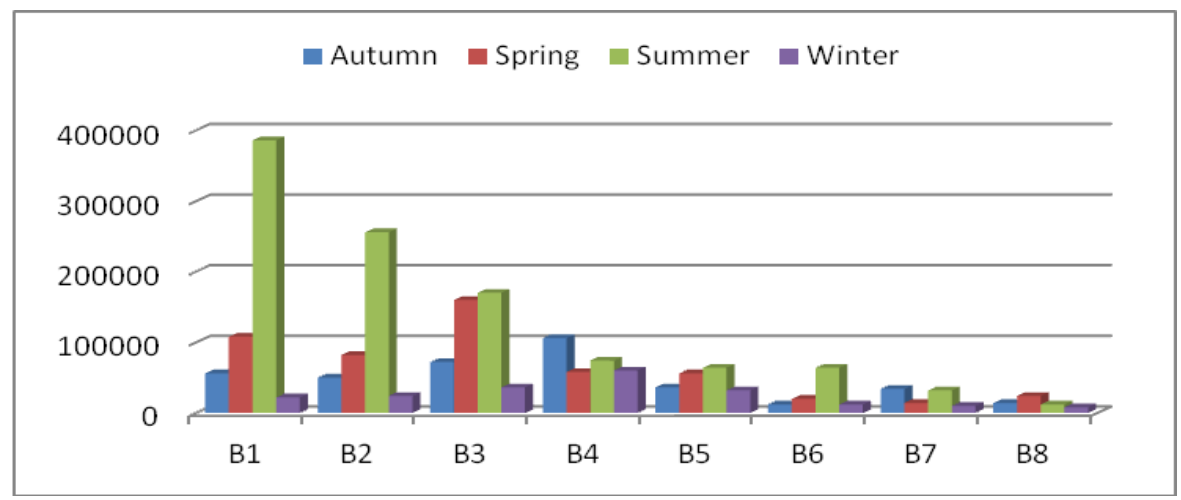

Fig. 5: Distribution and seasonal variation of Protozoa in El-Rayah El-Behery 
Nine protozoan species belonged to 6 genera were identify during this study. Vorticellac campanula was the most abundant protozoan and it contributed about $42.1 \%$ of the total Protozoa populations, it flourished in summer with highest population density of $67250 \mathrm{Ind} . / \mathrm{m}^{3}$ but the lowest one $\left(4500 \mathrm{Ind} . / \mathrm{m}^{3}\right)$ was recorded during winter. Gideon et al. (2014) considered Vorticella campanula as one of species which are indicators of high water pollution status.

Cluster analysis of protozoa at El-Rayah El-Behery showed that, the sampling sites divided between two major clusters with low percentage of similarity (more than $55 \%$ ). The first cluster included the stations from B1 to B5 with similarity nearly $75 \%$. The highest similarity value (more than 90\%) was detected between B2 and B3 .The second major cluster was included stations from B6 to B8 with similarity nearly $70 \%$, Figure (6). There was narrow difference in the diversity index and species richness of protozoa between the different stations during the present study, Table (4).

Table 4: Species diversity of total Protozoa in El-Rayah El-Behery during 2014.

\begin{tabular}{|c|c|c|c|c|c|}
\hline Sample & $\begin{array}{c}\text { No. of } \\
\text { species }\end{array}$ & $\begin{array}{c}\text { No .of } \\
\text { Individuals }\end{array}$ & Richness (d) & Evenness (J') & $\begin{array}{c}\text { Shannon } \\
\text { Index }\left(\mathrm{H}^{\prime}\right)\end{array}$ \\
\hline B1 & 9 & 143000 & 0.7 & 0.68 & 1.49 \\
\hline B2 & 9 & 103000 & 0.7 & 0.62 & 1.36 \\
\hline B3 & 9 & 109500 & 0.7 & 0.70 & 1.54 \\
\hline B4 & 9 & 74500 & 0.7 & 0.77 & 1.69 \\
\hline B5 & 8 & 47000 & 0.7 & 0.85 & 1.77 \\
\hline B6 & 6 & 27000 & 0.5 & 0.75 & 1.34 \\
\hline B7 & 8 & 22500 & 0.7 & 0.81 & 1.67 \\
\hline B8 & 6 & 14500 & 0.5 & 0.96 & 1.73 \\
\hline
\end{tabular}

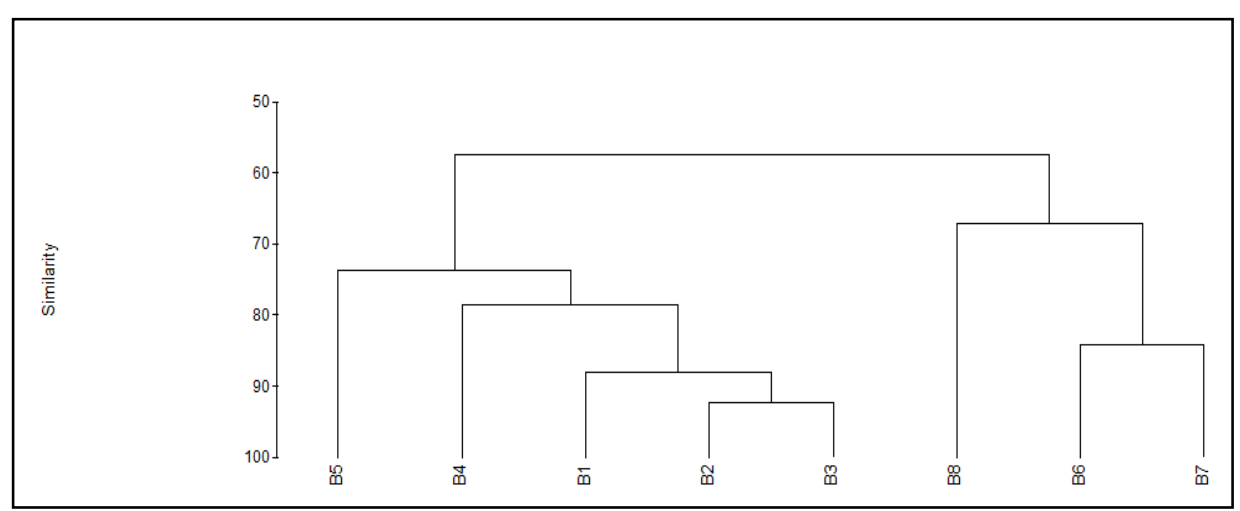

Fig. 6: Cluster analysis similarity between sampling sites of total Protozoa at El-Rayah El-Behery

\section{Cladocera}

Cladocera occupied the third position among the different zooplankton groups in the area of study. The highest population density of cladocera was recorded in winter while the lowest population density was observed during summer. It showed positive correlation with temperature. El-Bassat (2002) mentioned that, temperature plays a major role in the distribution of cladocera and most cladoceran species prefer low temperature. Abd El-Karim (1999) and Bedair (2006) mentioned that, the decreasing in the density of cladocera population during summer due to flourish of Blue green algae and dinoflagellates which lead to the inhibition of cladocera filtering 
rate. The population density of cladocera recorded the minimum value (14500 ind. $/ \mathrm{m}^{3}$ ) at B2 and increased to the maximum reading (57500 ind. $/ \mathrm{m}^{3}$ ) at B5 (Fig.7).

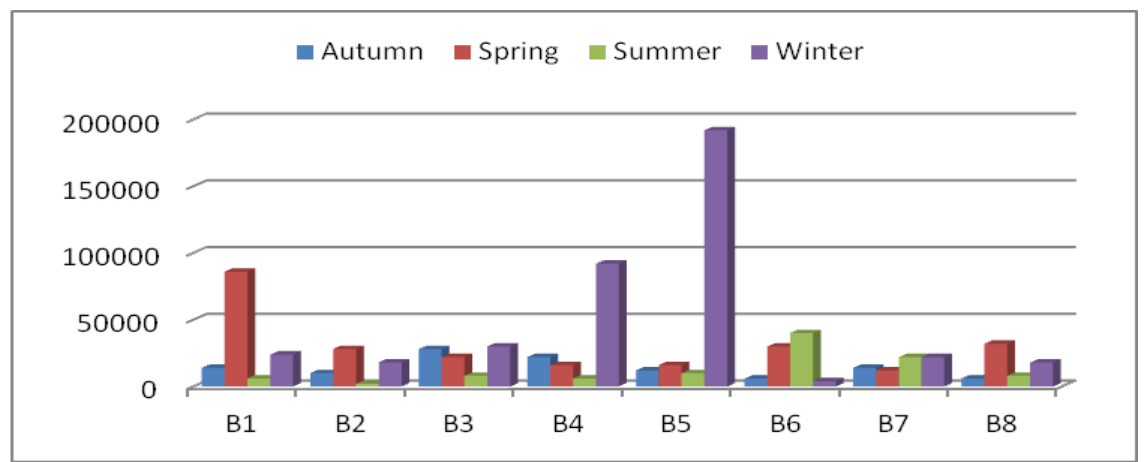

Fig.7: Distribution and seasonal variation of Cladocera in El-Rayah El-Behery

During this study, 7 species belonging to 5 genera of cladocera were identified. Bosmina longirostris was the most dominant species of cladocera and represented about 58.9\%total cladocera. Bedair (2006) mentioned that, the dominance of $B$. longirostris was attributed to its ability to tolerate turbidity. It flourished during winter season and recorded average number 41500 ind. $/ \mathrm{m}^{3}$ respectively, while it decreased to the minimum average during summer.

Cluster analysis of cladocera at El-Rayah El-Behery showed that, the sampling sites divided between two major clusters with similarity nearly $60 \%$. Within The first cluster B6 was located in separate position and has the minimum number of species and richness $(\mathrm{S}=4$ and $\mathrm{d}=0.3$ ), while $\mathrm{B} 7$ and $\mathrm{B} 8$ were located in the second sub cluster with similarity about $85 \%$ and have the same number of species and richness $(S=6$ and $\mathrm{d}=0.5$ ). The second major cluster divided into two sub-clusters with similarity about $70 \%$ (Table 4; Fig. 8).

Table 5: Species diversity of total Cladocera in El-Rayah El-Behery during 2014.

\begin{tabular}{|c|c|c|c|c|c|}
\hline Sample & $\begin{array}{c}\text { No. of } \\
\text { species }\end{array}$ & $\begin{array}{c}\text { No .of } \\
\text { Individuals }\end{array}$ & Richness (d) & Evenness (J') & $\begin{array}{c}\text { Shannon } \\
\text { Index }\left(\mathrm{H}^{\prime}\right)\end{array}$ \\
\hline B1 & 7 & 32500 & 0.6 & 0.77 & 1.50 \\
\hline B2 & 5 & 14500 & 0.4 & 0.73 & 1.17 \\
\hline B3 & 7 & 22000 & 0.6 & 0.69 & 1.34 \\
\hline B4 & 5 & 34000 & 0.4 & 0.59 & 0.95 \\
\hline B5 & 8 & 57500 & 0.6 & 0.33 & 0.70 \\
\hline B6 & 4 & 20000 & 0.3 & 0.82 & 1.13 \\
\hline B7 & 6 & 17500 & 0.5 & 0.76 & 1.36 \\
\hline B8 & 6 & 16000 & 0.5 & 0.86 & 1.54 \\
\hline
\end{tabular}

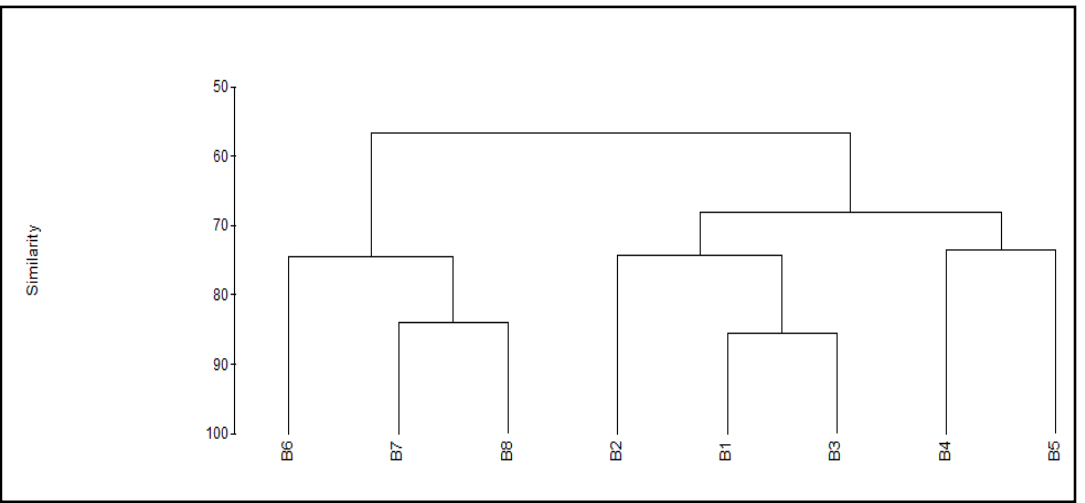

Fig. 8: Cluster analysis similarity between sampling sites of total Cladocera at El-Rayah El-Behery. 


\section{Copepoda}

Copepoda was the last group of zooplankton and represented by 3 species and 2 larval stages (Nauplius larvae and copepodite cyclopoid). This result was agreed with Hegab (2010) and Gaber (2013). The maximum peak of copepod was recorded during spring, this result may be due to the abundance of Naupillus larvae and the copepodite stages during this period. Nauplius larvae formed the highest bulk of total copepod and followed by copepodite stages. It recorded about $74.8 \%$ of total copepods with average of 13188 ind.$/ \mathrm{m}^{3}$ and the lowest standing crop (4000 ind. $/ \mathrm{m}^{3}$ ) was collected from B4 and B5, it increased to the highest average of 52000 ind. $/ \mathrm{m}^{3}$ at B6. It flourished during summer and spring, while it decreased to the minimum values during winter. This may be attributed to the effect of high water temperature which accelerates the copepods' production in the presence of high nutrient concentrations. This agrees with El-Bassat (2002) who stated that the maximum abundance of this group was attributed to the high concentration of nutrients and high transparency; this explains the high peaks of copepod at the last three stations of ElRayah El-Behery.

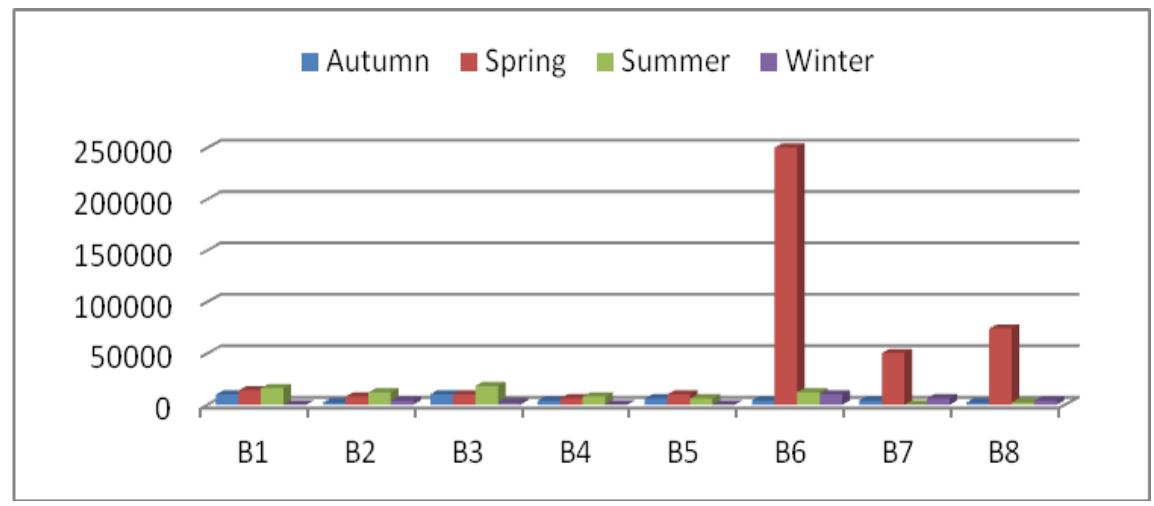

Fig. 9: Distribution and seasonal variation of Copepoda in El-Rayah El-Behery

The sampling sites were divided according to the cluster analysis of copepods into two major clusters with similarity 55\%. The first one divided into two sub cluster with similarity $75 \%$. The stations B2 \& B4 and B5 were represented the first sub cluster with similarly about $90 \%$ and have the same number of species and richness $(\mathrm{S}=2$ and $\mathrm{d}=0.1)$. Within the second sub cluster B1 and B7 were recorded the highest similarity (more than 90\%). The second major cluster included stations B6 and B8 with similarity nearly $70 \%$ (Table 6 and Fig. 10).

Table 6: Species diversity of total Copepoda in El-Rayah El-Behery during 2014.

\begin{tabular}{|c|c|c|c|c|c|}
\hline Sample & $\begin{array}{c}\text { No. of } \\
\text { species }\end{array}$ & $\begin{array}{c}\text { No .of } \\
\text { Individuals }\end{array}$ & Richness (d) & Evenness $\left(\mathbf{J}^{\prime}\right)$ & $\begin{array}{c}\text { Shannon } \\
\text { Index }\left(\mathbf{H}^{\prime}\right)\end{array}$ \\
\hline B1 & 3 & 10000 & 0.2 & 0.68 & 0.75 \\
\hline B2 & 2 & 6500 & 0.1 & 0.62 & 0.43 \\
\hline B3 & 2 & 10000 & 0.1 & 0.72 & 0.50 \\
\hline B4 & 2 & 4500 & 0.1 & 0.50 & 0.35 \\
\hline B5 & 2 & 5500 & 0.1 & 0.85 & 0.59 \\
\hline B6 & 4 & 69500 & 0.3 & 0.45 & 0.63 \\
\hline B7 & 3 & 15500 & 0.2 & 0.53 & 0.58 \\
\hline B8 & 4 & 28000 & 0.3 & 0.82 & 1.14 \\
\hline
\end{tabular}




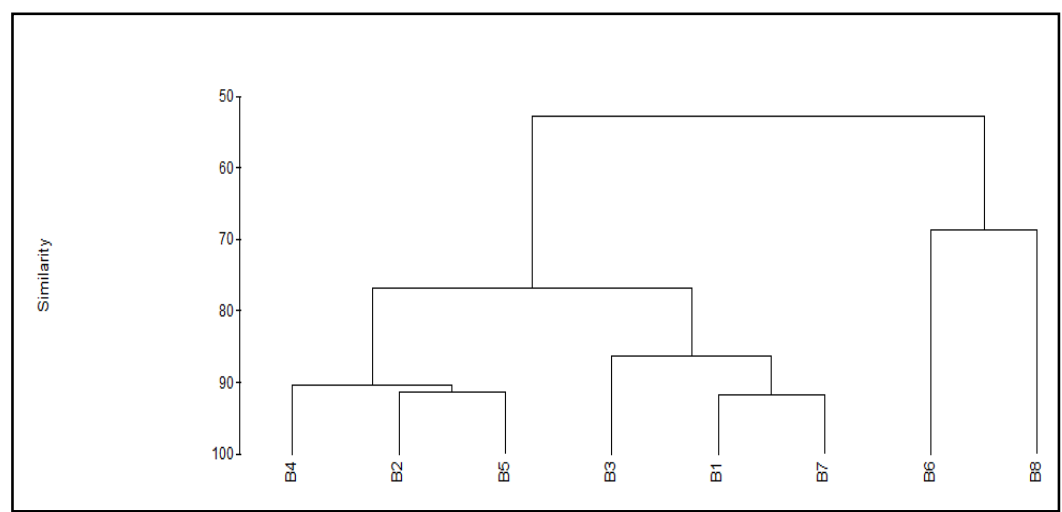

Fig. 10: Cluster analysis similarity between sampling sites of total Copepoda at El-Rayah El-Behery

\section{Canonical Correspondence Analysis (CCA)}

The environmental variables were affected on rotifer species according to CCA analysis with percentage $82 \%$ and the relation between them was very closely relation according to the value of correlation coefficient (0.99). The most effective variables were $\mathrm{EC} \& \mathrm{PO}_{4}$ and $\mathrm{NH}_{3}$ which showed high positively correlation with the species axis and recording correlation coefficient 0 . 9. DO was observed high negatively correlation with the species axis with correlation coefficient (- 0.7). The species are aggregated on one side except Brachionus calyciflouris (Figure, 11).

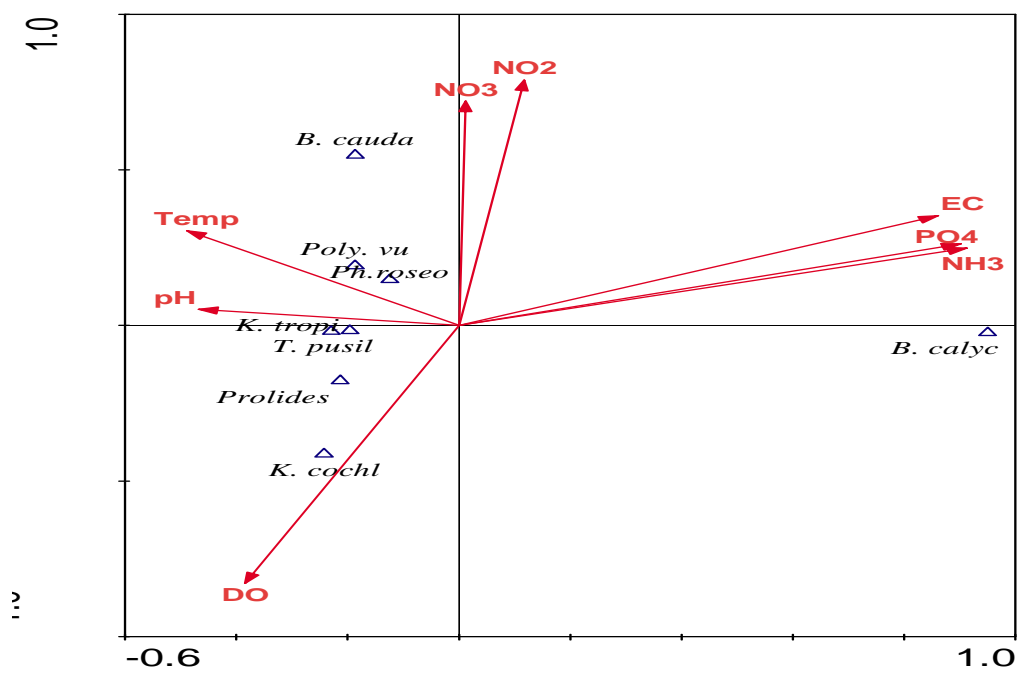

Fig.11: CCA of different environmental variables with Rotifer species at El-Rayah El-Behery

The relation between the environmental variables and protozoa's species of El-Rayah El-Behery was very closely relation according to the correlation coefficient (0.9) which obtained by CCA analysis. This value reflected the effect of environmental variables controlling protozoan species distribution with percentage about $67 \%$. The most controlling variable was temperature which showed high negative correlation with correlation coefficient -0.7 and followed by $\mathrm{NH}_{3}$ which record positive correlation with the species axis with correlation coefficient 0.6. The species were scattered in CCA biplot and there was high correlation between Paracentaceraniataand $\mathrm{pH} \&$ DO. Centropxis oculata has positive correlation with $\mathrm{PO}_{4}$ ( Fig.12). 


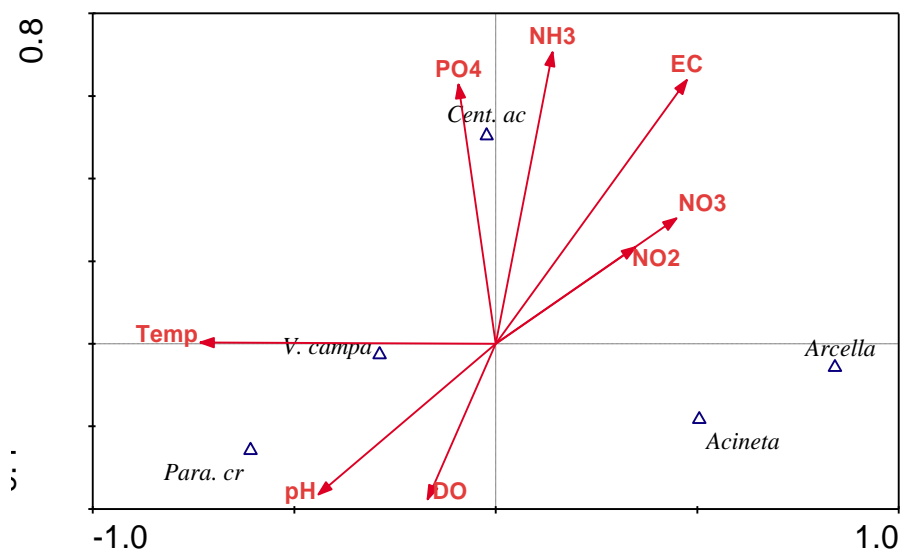

Fig.12: CCA of different environmental variables with Protozoan species at El-Rayah El-Behery

According to CCA biplot of environmental variable against cladoceran species composition at El-Rayah El-Behery, The correlation coefficient between the first environmental variable axis and species composition axis was 0.9 and the most controlling factor on cladoceran community was temperature, with correlation coefficient 0.8 . The species are scattered between the canonical axes, indicating the different effect of the variables on each species. Bosminalongirostrius was affected by $\mathrm{EC} \& \mathrm{PO}_{4}$ and $\mathrm{NH}_{3}$ and there was high correlation between cladocera embryo and pH (Fig. 13).

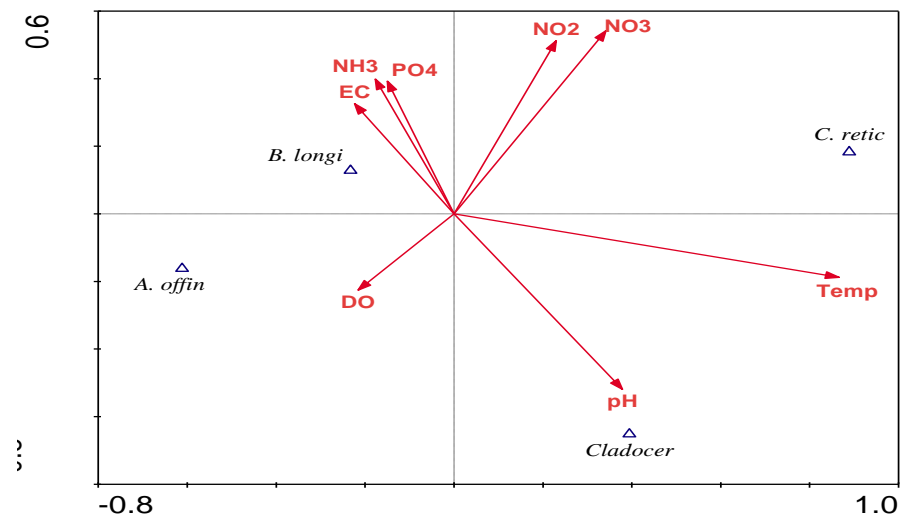

Fig.13: CCA of different environmental variables with Cladoceran species at El-Rayah El-Behery

\section{ACKNOWLEDGMENT}

I would like to extend my thanks and gratitude to Dr. Gamal Al-Shabrawy Prof. of aquatic invertebrates at NIOF, and Dr. Mohamed Abo Zeid Prof. of Aquatic Biology, Department of Zoology, Faculty of Science, Al-Azhar University (May God have mercy on them) for following up this work, and I call upon them for mercy and forgiveness.

\section{REFERENCES}

Abd El-Aziz, N.E. (2005). Short term variations of zooplankton community in the west Naubaria Canal, Alexandria, Egypt. Egy. J. Aqua. Res., 31 (1): 119-131.

Abd El-Aziz, N. E. and Aboul Ezz, S. M. (2004). The structure of zooplankton community in Lake Maryout, Alexandria, Egypt. Egy. J. Aqua. Res., 30 (A): 160-170. 
Abd El-Hamid, M.I.; Shaaban, D.S.A and Skulbery, O.M. (1992). Water quality of the River Nile in Egypt. (i) Physical and chemical characteristics. Arch, Hydrobiology. Suppl., 90(3):283-310.

Abd El-Karim, M. S. (1999). Phytoplankton dynamic and its productivity in Damietta Branch. M. Sc. Thesis, Girls College for Arts, Education \& Science. Ain Shams Univ., $202 \mathrm{pp}$.

Abd El-Mageed, A. A. (2001). Zooplankton composition of some Industrial polluted areas in the River Nile ecosystem. Egy. J. Aqua. Biol. Fish., 5 (2): 1-20.

Abd El-Mageed, A. (2008). Distribution and long-term historical changes of zooplankton assemblages in Lake Manzala (South Mediterranean Sea,Egypt). Egy. J. Aqua. Res., 33(1): 183-192.

Abd El- Satar, A.M. (2005). Water Quality of River Nile Sediments from Idfo to Cairo. Egyp. J. Aqua. Res., 31(2): 182 - 199.

Abd El-Satar, M. A. (2008). Chemistry of major ions, nutrient salts and heavy metals in Lake Manzalah, Egypt. Egy. J. Aqua. Res., 34(2): 130 -148.

Abdo, M, H. (2013). Physico- Chemeical Studies on the Pollutants Effect in the Aquatic Environment of Rosetta Branch River Nile, Egy. Lif. Sci. J., 10 (4).

Abdo, M. H.; Sabae, S. Z.; Haroon, B. M.; Rafaat, B. M. and Mohammed, A. S. (2010). Physicochemical characteristics, Microbial Assessment and Antibiotic Susceptibility of Pathogenic Bacteria of Ismailia Canal water, River Nile, Egypt. J. of Amer. Sci., 6(5): 234 - 250.

Abo-Taleb, H.A.H. (2009). Dynamics of zooplankton community in the connection between the Mediterranean Sea and The River Nile at Rosetta branch. Egypt. B. Sc. Fac. of Sci. Al-Azhar University, 181pp.

Aboul-Ezz, S. M.; Salem, S. A.; Samaan, A. A.; Latif, A. F. A. and Soliman, A. A. (1996). Distribution of rotifers in the Rosetta Nile branch (Egypt).J. Egy. Ger. Soc. Zool., 20 (D): 85-123.

Amer, A. S. (2007). Effect of different types of pollutants on Bacteria-Zooplankton interaction in the Nile water. Ph. D. Thesis, Fac. Of Science, Zool. dep., Girls College, Ain Shams University. 227pp.

Andrew, T. E. and Fizsimous, A. G. (1992). Seasonality, population dynamics and production of planktonic Rotifers in Lough Neagh, Northern Ireland. Hydrobiologia, 246: 147-164.

Armorek, D. R. and Korman. J. (1993). The use of zooplankton in a biomonitoring program to detect lake acidification and recovery. Water, Air, Soil Poll., 69(34):223-241.

Bedair, S. M. (2006). Environmental studies on zooplankton and phytoplankton in some polluted areas of the River Nile and their relation with feeding habit of fish. Ph. D. Thesis, Fac. Of Sci. Zagazig Uni.

Carpenter, S. R. and Kitchell, J. F. (1993). The trophic cascade in lakes. Cambridge University Press. Cambridge, U.K.

Caulleaud, K.; Forget-Leray, J.; Peluhet, L.; Lemenach, K.; Souissi S.; Budzinski, H. (2009). Tidal influence on the distribution of hydrophobic organic contaminants in the Seine Estuary and biomarker responses on the copepod Eurytemora affinis. Environ. Pollut, 157(1): 64-71.

Cuker, B.E. (1997). Field experiment on the influence of suspended clay on the plankton of a small lake. Limnology and Oceanography, 32: 840-847.

Dodson, S. (1992). Predicting crustacean zooplankton species richness. Limnol. Oceanogr., 37: 848-856. 
Edmondson,W.T. (1959). Reproductive rate of planktonic Rotifers as related to food and temperature in nature. Ecolo. Monog., 35(1): 66-1111.

El-Bassat, R. A. (1995). Ecological studies of zooplankton on the River Nile. M. Sc. Thesis, Fac. Of Sci., Suez canal Univ., 199 pp.

El-Bassat, R. A. (2002). Ecological studies on zooplankton communities with particular reference to free living protozoans at River Nile - Damietta Branch. Ph. D. Thesis, Wom. Coll. For Arts, Educ. \& Sci., Ain Shams Univ.

El-Bouraie, M. M.; El Barbary, A. A.; Yehia, M. M.and Motawea, E. A. (2011). Determination of Organochlorine Pesticide (OCPs) in Shallow Observation Wells from El Rahawy Contaminated Area, Egy. Env. Res., Eng. and Mana. , 3(57): 28-38.

El-Shabrawy, G. M. (2000). Seasonal and spatial variation in zooplankton structure in Lake Nasser. Pelagic area of the main channel, Egypt. Egy. J. of Aquatic Biol.and Fish., 4: 61-84.

El-Shabrawy, G. M.; Elowa, Sh. E.; Rizk, S.T and El-Fetouh, O.M. (2005). Impact of industrial pollution on zooplankton community structure in Rosetta Nile Branch at Kafr El-Zayat area, Egypt. Afri. J. Biol. Sci., 1 (1): 1-14.

El-Shabrawy, G.M. and Dumont, H.J. (2003). Spatial and seasonal variation of the zooplankton in the coastal zone and main khors of Lake Nasser, Egypt. Hydro., 49: 119-132.

El-Shabrawy, G. M. and Germoush, M. O. A. (2014). Seasonal changes and abundance of rotifers in a shallow Manzalah Lake, Egypt. Ecoh. Hydro., $14: 243-252$.

Elewa, A. A. (1993). Distribution of $\mathrm{Mn}, \mathrm{Cu}, \mathrm{Zn}$ and $\mathrm{Cd}$ in water, sediments and aquatic plants in River Nile and Aswan Reservoir, Egypt. J. Appl. Sci., 8(2): 711-723.

Emam,W. (2006). Preliminary study on the impact of water pollution in El-Rahawy drain dumping in Rosetta Nile branch on zooplankton and benthic invertebrates. M. Sc. Thesis, Zoo. Dep. Fac. of Sci. Ain Shams Uni.

Fathi, A. A. and Al-Kahtani, M. A. (2009). Water Quality and Planktonic Communities in Al-Khadoud Spring, Al-Hassa, Saudi Arabia. Ame. J. of Envi. Sci., 5 (3), 434-443.

Fleeger John, W.; Kevin, R. and Roger, M. (2003). Indirect effects of contaminants in aquatic ecosystems. Sci. of Env., 317: 207-233.

Foissner, W. and Berger, H. (1996). A user-friendly guide to the ciliates (Protozoa, Cilliophora) commonly used by hydro biologists as bioindicators in rivers, lakes and waste waters, with notes on their ecology. Fresh. Biol., 35(2): 375482.

Gaber, K, M. (2013). Studies on the distribution and diversity of zooplankton in River Nile and its branches (Rosetta and Damietta branches), Egypt. M. Sc. Thesis, Fac. Sci., Al-Azhar Univ., Cairo, 198 pp.

Galkovskaja, G. A. (1987). Planktonic rotifers and temperature. Hydro. 147:307-317. George, M. N. (2012). Ecological studies on aquatic invertebrates of Ismalia Canal, Egypt. M. Sc. Thesis, Fac. of Sci, Ain Shams Univ.

Gideon, A. A., Mirela, P., Maria, C., Constantin, O, Palela, M., and Bahrim, G. (2014). Biological and Physico-Chemical Evaluation of the Eutrophication Potential of a Highly Rated Temperate Water Body in South-Eastern Romania. J. Env. Eco., 5 (2), 108-129. 
Gohar, M.A. (1998). Factors affecting the precipitation and dissolution of some chemical elements in River Nile at Damietta branch. M. Sc. Thesis fact. of Sci. Menofia Univ. Egypt.

Hegab, M. H. (2010). Effect of some environmental parameters on distribution of zooplankton and the relationship between them and food \& feeding of some fish in Rosetta Branch of River Nile, Egypt. M. Sc. Thesis, Fac. Sci., Al-Azhar Univ., Cairo, 243pp.

Khalifa, N. S. (2000). Study on the impact of industrial wastes at Helwan on River Nile zooplankton. Ph. D. Thesis, Fac. of Sci, Cairo Univ.

Khalifa, N. S. (2014). Population dynamics of rotifera in Ismailia Canal,Egypt. J. of Bio. Env. Sci., 4(2):58-67.

Khalifa, N. S. and Bendary, R. E. (2016). Composition and Biodiversity of zooplankton and Macrobenthic populations in El-Rayah El-Menoufy, Egypt. Inter. J. App. Env. Sci., 11(2):683-700.

Kobbia, I. M.; Metwali, R. M.; El-Adel, H. M. (1995). Influence of water effluents of soap and oil factory at Benha on Nile phytoplankton communities. Egy. J. of Bot., 35, 45-57.

Koste, W. (1978). Rotatoria. Die Rädertiere Mitteleuropas. Gebrüder Borntraeger 1(2), Berlin, $673 \mathrm{pp}+234 \mathrm{pl}$.

Kumari, P.; Dhadse, S.; Chaudhari, P. R. and Wate S. R. (2008). A biomonitoring of plankton to assess quality of water in the lakes of Nagpur city. In: Sengupta M. and Dalwani R. (Eds). Proc. of Taal. The 12th World Lake Conference, 160164.

McCallum, I. D. (1979). A simple method of taking subsample of zooplankton. N. Z. J. Mar. Fresh. Res., 13:559-560.

Moustafa, M. M.; Ali, M. H. H.; Abdel-Satar, A. M.; Mohamed, T. Y. and Madbouly, S. M., (2010). Water quality assessment of Rosetta and Damietta branchs, River Nile, Egypt. Afri. J. Biol. Sci., 6(2), 127-142.

Mola, H. R. A. (2011). Seasonal and spatial distribution of Brachionus (Palla, 1966; Eutotatoria: Monogonanta: Brachionidae), a bioindicator of eutrophication in lake El-Manzalah, Egypt. Biol. Medi., 3 (2): 60-69.

Pejler, B. and Bērziņš, B. (1989). On chice of substrate and habitat in brachionid rotifers. Hydro., 186(187), 137-144.

Perbiche-Neves, G.; Fileto, C.; Laçoportinho, J.; Troguer, A. and Serafim-Júnior, M., (2013). Relations among planktonic rotifers, cyclopoid copepods, and water quality in two Brazilian reservoirs. Amer. J. Aqua. Res., 41 (1), 138-149.

Saad, S. M. M.; El-Deeb, A. E.; Tayel, S. I. and Ahmed N. A. M. (2011). Haematological and histopathological studies on Claris gariepinus in relation to water quality along Rossetta branch, River Nile, Egypt. Egy. J. Exp. Biol. (Zool.), 7(2), 223-233.

Saad, A. A.; Emam, W. M.; El-Shabrawy, G. M and Gowedar, F. M. (2013). Sewage pollution and zooplankton on assemblage along the Rosetta branch at ElRahawy area, Egypt. Inter. J. Envi. Sci. Engi., 4: 29-45.

Sabae, S. Z. (2004). Monitoring of microbial pollution in the River Nile and the impact of some Human activities on its waters, Proc. $3^{\text {rd }}$ Int. Conf. Biol. Sci. Fac. Sci. Tanta Univ., 28-29 April, vol. 3: 200-214.

Sayed, M. F. (2003). Chemical studies on pollution in Rosetta branch of River Nile between Kafr E 1-Zayat and Rosetta outlet, Ph.D. Thesis, Fac. Sci., Cairo Unv.

Shama, S. A.; Goher, M. E.; Abdo, M. H.; Kaial, S. M. And Ahmed, A. A. (2011). Physico-chemical characteristics and heavy metal content in water of Wadi El- 
Rayan Lakes, Western desert, Egypt. Egypt. J. Aquat. Biol. And Fish., 15(2): 225-240.

Stahl, R. and Ramadan, A. B. (2008). Environmental Studies on Water Quality of the Ismailia Canal, Egypt. Scientific Report, Forschungszentrum Karlsruhe in der Helmholtz-Gemeinschaft Wissenschaftliche Berichte FZKA 7427.

Stemberger, R. S. and Chen,C.Y. (1998). Fish tissue metals and zooplankton assemblages of northeastern U.S. lakes. Can. J. Fish. Aquatic. Sci. 55: 339-352.

Tayel, S. I. M. (2003). Histopathological, biochemical and Hematological studies on Tilapia zillii and Claries gariepinus In relation to water quality criteria at different localities in Delta Barrage. Ph. D. Thesis, Fac. of Sci. Benha branch. Zagazig Univ. Egypt.

Van Dijk, G. M. and Van Zanten, B. (1995). Seasonal changes in zooplankton abundance in the lower Rhine during 1987-1991. Hydro., 304:29-38.

Yan, N. D., K Keller, W.; Somers, K. M.; Pawson, T. W. and Girard; R.E. (1996). Recovery of crustacean zooplankton communities from acid and metal contamination: comparing manipulated and reference lakes. Cana. J. Fish. Aquat. Sci., 53:1301-1327. 